\title{
Sympathetic neuroblasts undergo a developmental switch in trophic
} dependence

\author{
Susan J. Birren', Liching Lo² and David J. Anderson ${ }^{2, *}$ \\ ${ }^{1}$ Division of Biology 216-76, ${ }^{2}$ Howard Hughes Medical Institute, California Institute of Technology, Pasadena, CA 91125 , \\ USA \\ *Author for correspondence
}

\section{SUMMARY}

Sympathetic neurons require NGF for survival, but it is not known when these cells first become dependent on neurotrophic factors. We have examined in vitro mitotically active sympathetic neuroblasts immuno-isolated from different embryonic stages, and have correlated this functional data with the expression of neurotrophin receptor mRNAs in vivo. Cells from E14.5 ganglia are supported by neurotrophin-3 (NT-3) in a serum-free medium, but not by NGF; NT-3 acts as a bona fide survival factor for these cells and not simply as a mitogen. By birth, sympathetic neurons are wellsupported by NGF, whereas NT-3 supports survival only weakly and at very high doses. This change in neurotrophin-responsiveness is correlated with a reciprocal switch in the expression of trkC and $\operatorname{trkA}$ mRNAs by sympathetic neuroblasts in vivo. These data suggest that neurotrophic factors may control neuronal number at earlier stages of development than previously anticipated. They also suggest that the acquisition of NGFdependence may occur, at least in part, through the loss of receptors for these interim survival factors.

Key words: neuroblast, sympathetic neuroblast, NGF, neurotrophic factor

\section{INTRODUCTION}

Vertebrate neurons are typically generated in excess numbers over their postsynaptic targets, and the supernumerary cells are later culled until an appropriate match between innervation and target field size is achieved (Cowan et al., 1984). This elimination of excess neurons is thought to occur by competition for limiting quantities of survival factors, called neurotrophins, secreted by the target (Purves and Lichtman, 1985). If excess neurotrophin molecules are experimentally introduced to the system, neurons that ordinarily would have died are rescued (Angeletti et al., 1971; Hamburger et al., 1981). Conversely, if the concentration of neurotrophins is experimentally reduced (for example, by using blocking antibodies), then neurons that ordinarily would have survived, die (Levi-Montalcini and Booker, 1960; Rohrer et al., 1988). Such fine tuning of cell number can occur because these neurons are apparently programmed to undergo apoptosis in the absence of neurotrophic support (Martin et al., 1988). This process of target control of neuronal survival is fundamental to vertebrate neurogenesis, but is not yet adequately modeled by invertebrate systems amenable to genetic analysis (although programmed cell death has been genetically demonstrated in these systems (Ellis et al., 1991)).

Substantial progress has recently been made in understanding the molecular basis of trophic control of neuronal survival. Neurotrophins comprise a family of four distinct genes, all of which encode proteins structurally related to Nerve Growth Factor (NGF) (Levi-Montalcini and Angeletti, 1968), the first neurotrophin to be purified, sequenced and cloned. Purification and sequencing of the second neurotrophin, Brain-Derived Neurotrophic Factor (BDNF) (Leibrock et al., 1989) led to the isolation, via homology cloning, of neurotrophins 3 and 4/5 (NT-3 and NT-4/5) (for review, see Thoenen, 1991). Studies in cell culture have demonstrated that each of these neurotrophins supports distinct but overlapping classes of neurons. This diversity of action is reflected in the distinct expression patterns exhibited by these genes in vivo (Maisonpierre et al., 1990a).

The molecular diversity of neurotrophins is mirrored by a corresponding diversity of their receptors. Neurotrophins interact with two structurally distinct classes of receptors on the cell surface: a member of the trk family of receptor tyrosine kinases; and a low-affinity transmembrane receptor called p75. All of the neurotrophins interact with p75 (Rodriguez-Tébar et al., 1990), but each of them displays distinct high-affinity interactions with a member of the trk family (for review, see Bothwell, 1991). NGF interacts specifically with trkA, BDNF interacts with trkB, NT-3 interacts with trkC (and to a lesser extent with trkB and trkA) and NT-4/5 interacts primarily with trkB (for review, see Meakin and Shooter, 1991). The interaction of neurotrophins with their receptors is thought to provoke an intracellular signalling cascade involving the c-ras GTPase 
(Kremer et al., 1991), analagous to the pathways recently described for signal transduction through receptor tyrosine kinases via genetic analysis in Caenorhabditis elegans and Drosophila (for reviews, see Rubin, 1991; Sternberg and Horvitz, 1991).

Relatively little is understood about when and how developing neurons become dependent upon trophic support during development. Peripheral sensory and sympathetic ganglia have served as useful model systems for the investigation of these issues because of their relative simplicity and experimental accessibility, and because the neurotrophins for these ganglia have been relatively welldefined. Sympathetic neurons are thought to be supported primarily by NGF, whereas sensory neurons are supported by NGF, BDNF and, to some extent, NT-3 (Chun and Patterson, 1977; Levi-Montalcini and Angeletti, 1963; Lindsay et al., 1985; Maisonpierre et al., 1990b). In principle, neurons could survive independently of trophic factors until they began to innervate their targets, at which point they would acquire such a dependence. Alternatively, neurons and their precursors could be constitutively programmed to die unless supported by trophic factors of one sort or another, in which case the nature of the trophic factor and its source of production might change as the developing neuron reached its target.

Recent in situ hybridization experiments have revealed that some neurotrophin mRNAs are expressed in embryonic sympathetic ganglia, raising the possibility that these factors could play a role at early stages of neurogenesis (Schecterson and Bothwell, 1992). Studies of embryonic mouse and chick sympathetic and sensory neurons in vitro have suggested that these cells survive independently of NGF at early developmental stages (Coughlin and Collins, 1985; Ernsberger et al., 1989; Vogel and Davies, 1991). However, these studies have been performed using heterogeneous mass cultures and serum-containing culture media, both of which could provide sources of exogenous growth factors. Here we have investigated the trophic requirements of immuno-isolated sympathetic neuroblasts grown in a serumfree defined medium. We find that these cells are initially supported by NT-3, but not by NGF. Subsequently, the cells acquire NGF responsiveness and are supported much less well by NT-3. This switch in neurotrophin responsiveness in vitro is correlated with a reciprocal switch in trkC and trkA mRNA expression in vivo. These data indicate that sympathetic neuroblasts require interim survival factors while they are still proliferating and before they become NGF dependent. NGF dependence is achieved through the induction of expression of NGF receptors and the extinction of expression of receptors for the interim trophic factor NT3.

\section{MATERIALS AND METHODS}

\section{Isolation and culture of primary rat sympathetic precursor cells and neurons}

Sympathetic ganglia were dissected from embryonic Simonson white rats (Simonson Laboratories) at 14.5 and 19.5 days of gestation (assuming the date of the plug as 0.5). The sympathetic chains were removed from the cervical to the lumbar region and were dissociated by treating the ganglia with $1.5 \mathrm{mg} / \mathrm{ml}$ collagenase (Worthington) and $1.0 \mathrm{mg} / \mathrm{ml}$ elastase (Sigma) made up in Hepes-buffered SMEM (HMEM-Gibco) for 30 minutes at $37^{\circ} \mathrm{C}$. A small aliquot of cells was reserved for use as a negative control for antibody staining, and the rest of the preparation was treated with the B2 antibody (1:1 dilution of a hybridoma supernatant) for 30 minutes at room temperature. The cells were washed once and further incubated with a fluorescein-conjugated goat anti-mouse IgM secondary antibody (TAGO) for 30 minutes at room temperature. B2-positive cells were isolated on a Epics Elite Fluorescence-Activated-Cell Sorter (Coulter). Viable cells were counted on a hemacytometer by trypan blue exclusion (Gibco) and plated into the wells of 24-well dishes (Fisher) that had been treated with poly-D-lysine (Biomedical Technologies) and laminin (Collaborative Research). The $\mathrm{B} 2^{+}$sympathetic precursor cells were grown in a defined, serum-free medium that was a modification of L15N2 medium (Wolinsky et al., 1985) and consisted of ${\mathrm{L} 15 \mathrm{CO}_{2}}_{2}$ containing 1:1:2 (glutamine/penicillin-streptomycin/gluocse) and fresh vitamin mix (FVM) (Hawrot and Patterson, 1979) with the following additions: $100 \mu \mathrm{g} / \mathrm{ml}$ transferrin (Sigma), $16 \mu \mathrm{g} / \mathrm{ml}$ putrescine (Sigma), $20 \mathrm{nM}$ progesterone (Sigma) and $30 \mathrm{nM}$ selenious acid (Aldrich). Note that this medium does not contain insulin.

Neonatal rat sympathetic neurons were obtained from the superior cervical ganglia (SCG) of postnatal day 1 Simonson white rats. The ganglia were dissected out and dissociated with $5.0 \mathrm{mg} / \mathrm{ml}$ dispase (BMB) and $1.0 \mathrm{mg} / \mathrm{ml}$ collagenase made up in Hepesbuffered SMEM for 1 hour at $37^{\circ} \mathrm{C}$. The cells were triturated through a fire-polished pasteur pipette and were preplated onto an untreated $60 \mathrm{~mm}$ tissue culture dish to permit the attachment of flat cells in the preparation. After 2 hours the enriched neuron population was removed and plated onto the wells of 24-well dishes that had been coated with poly-D-lysine and laminin. The neurons were cultured in the defined, serum-free medium described above.

\section{Cell recovery and proliferation assays}

$\mathrm{B} 2^{+}$sympathetic precursor cells or neonatal SCG neurons were plated at a density of 2500 cells/well in 24-well dishes. After 2-3 hours factors were added to the cultures and strips of cells were counted in each well and the total number of attached cells calculated. Unless otherwise noted, NGF (UBI) and purified, recombinant NT3 (provided by George Yancopoulos, Regeneron Pharmaceuticals, Tarrytown, NY) were used at $25 \mathrm{ng} / \mathrm{ml}$ and aurintricarboxylic acid (ATA, Sigma) at $25 \mu \mathrm{M}$. The cells were incubated at $37^{\circ} \mathrm{C}$ in a humidified, $5 \% \mathrm{CO}_{2}$ atmosphere. After 24 hours, the cells were fixed by gently underlayering $0.5 \mathrm{ml}$ of HMEM containing 3.7\% formaldehyde, $5 \%$ sucrose, $20 \%$ FBS and $0.02 \%$ azide.

Several procedures were employed to minimize sampling error in the cell-recovery assays. First, determinations in each well or plate at the end of the experiment were normalized to the number of cells initially present on that same plate at the beginning of the experiment ('percentage cell recovery'), thereby eliminating wellto-well variations in initial plating efficiencies. Second, all of the viable cells (distinguished by their round, phase-bright morphology) in each well or plate were counted at the end of the experiment, rather than simply counting cells in a few selected microscopic fields. This procedure minimizes sampling errors due to uneven cell distribution which compromises counts based on such selected fields. Typical determinations were $600-800$ cells per well in NT-3 and 200-300 cells per well in control or NGF (at E14.5). All determinations were made in triplicate for each condition in each experiment. Thus at least 2000-3000 cells in toto were counted for each experiment. We refer to 'percentage cell recovery' as our metric, rather than 'percentage cell survival,' because the cell population is proliferating and the relative contributions of cell division and survival to the total number of cells 
present at the end of the incubation are not distinguished by such assays. Each experiment reported was performed independently at least two times.

To assess the mitogenic effect of various factors, E14.5 sympathetic precursor cells were plated as described above and after 3 hours, $25 \mathrm{ng} / \mathrm{ml} \mathrm{NT3}$ or $10 \mathrm{ng} / \mathrm{ml}$ bFGF (R\&D Systems) was added and plating counts were determined. 8 hours before the end of the 24 hour culture period, BrdU (BMB) was added to a final concentration of $10 \mu \mathrm{M} .8$ hours later the cells were fixed for 30 minutes at $-20^{\circ} \mathrm{C}$ in $70 \%$ ethanol and stained for BrdU (Raff et al., 1988). Cells were washed three times with PBS to remove the ethanol and then treated for 10 minutes with $2 \mathrm{~N} \mathrm{HCl}$. The wells were again washed with PBS and treated an additional 10 minutes with $0.1 \mathrm{M}$ $\mathrm{Na}_{2} \mathrm{~B}_{4} \mathrm{O}_{7} \cdot 10 \mathrm{H}_{2} \mathrm{O}$. After further washing, the cells were incubated for 1 hour at room temperature with a 1:20 dilution of mouse anti$\mathrm{BrdU}(\mathrm{DAKO})$ and then for 1 hour with fluorescein-conjugated goat anti-mouse IgG (TAGO, 1:100). The cells were counterstained with DAPI ( $1 \mathrm{mg} / \mathrm{ml}$ for 5 minutes at room temperature) in order to visualize the nuclei. An in situ MTT assay (Barres et al., 1992) was carried out on sister cultures to determine the percentage of viable cells at the time of fixation, because the harsh pretreatments (ethanol fixation and acid extraction) used in the BrdU-labeling assay eliminated the good cell morphology used to assess cell viability in other experiments. The MTT assay was performed in sister cultures rather than as a double label with BrdU, because the MTT reaction product was solubilized by the fixation conditions used for the BrdU assay. 30 minutes before the end of the 24 hour culture period, MTT (Sigma) was added to final concentration of $0.5 \mathrm{mg} / \mathrm{ml}$ (Mosmann, 1983). After 30 minutes at $37^{\circ} \mathrm{C}$, the cells were fixed with $3.7 \%$ formaldehyde, the nuclei stained with DAPI and the percentage of DAPI-stained cells that showed the black MTT reaction product was determined for each condition. This number was then used to calculate the total number of viable cells in the BrdU-labeled cultures. Percentage cell recovery in the BrdU-labeled cultures was estimated dividing this number by the number of cells present after 3 hours (to correct for well-to-well variations in plating). While these procedures may introduce systematic errors that affect the magnitude of cell recovery or viability calculated, they should not affect a comparison of conditions between cultures processed and analyzed in the same way.

\section{Immunocytochemistry}

For immunocytochemical labeling, cells were fixed in HMEM containing $3.7 \%$ paraformaldehyde, $5 \%$ sucrose, $0.02 \%$ azide. Permeabilization was carried out using $0.1 \%$ Nonidet P-40 in phosphatebufffered saline (PBS) containing 1\% Normal Goat Serum, for 20 minutes at room temperature, prior to incubation with primary antibody. Monoclonal antibody to the $160 \times 10^{3} M_{\mathrm{r}}$ subunit of neurofilament was from Sigma Chemicals. Staining was visualized using a FITC-conjugated goat anti-mouse IgG (TAGO, Burlingame, CA). Neurotag is a RITC-labeled tetanus toxoid (Boehringer-Mannheim, Inc.) and was used to surface label formaldehyde-fixed neurons. Labeling was carried out for 1 hour at room temperature using $5 \mu \mathrm{g} / \mathrm{ml}$ Neurotag in PBS containing $0.1 \%$ bovine serum albumin.

\section{Nonradioactive in situ hybridization}

In situ hybridization with digoxigenin-labeled cRNA probes was performed on frozen sections of paraformaldehyde-fixed embryos, using a modification of the procedure developed for Xenopus embryos by Harland (Harland, 1991). A detailed protocol is available on request. Briefly, following pretreatments (Proteinase $\mathrm{K}$, postfixation, acetic anhydride) sections were dehydrated through an ethanol series and air dried. They were then prehybridized for $3-4$ hours at $60^{\circ} \mathrm{C}$. Hybridization was carried out for 12-16 hours using $1-2 \mu \mathrm{g} / \mathrm{ml}$ of probe, in plastic slide mailers con-
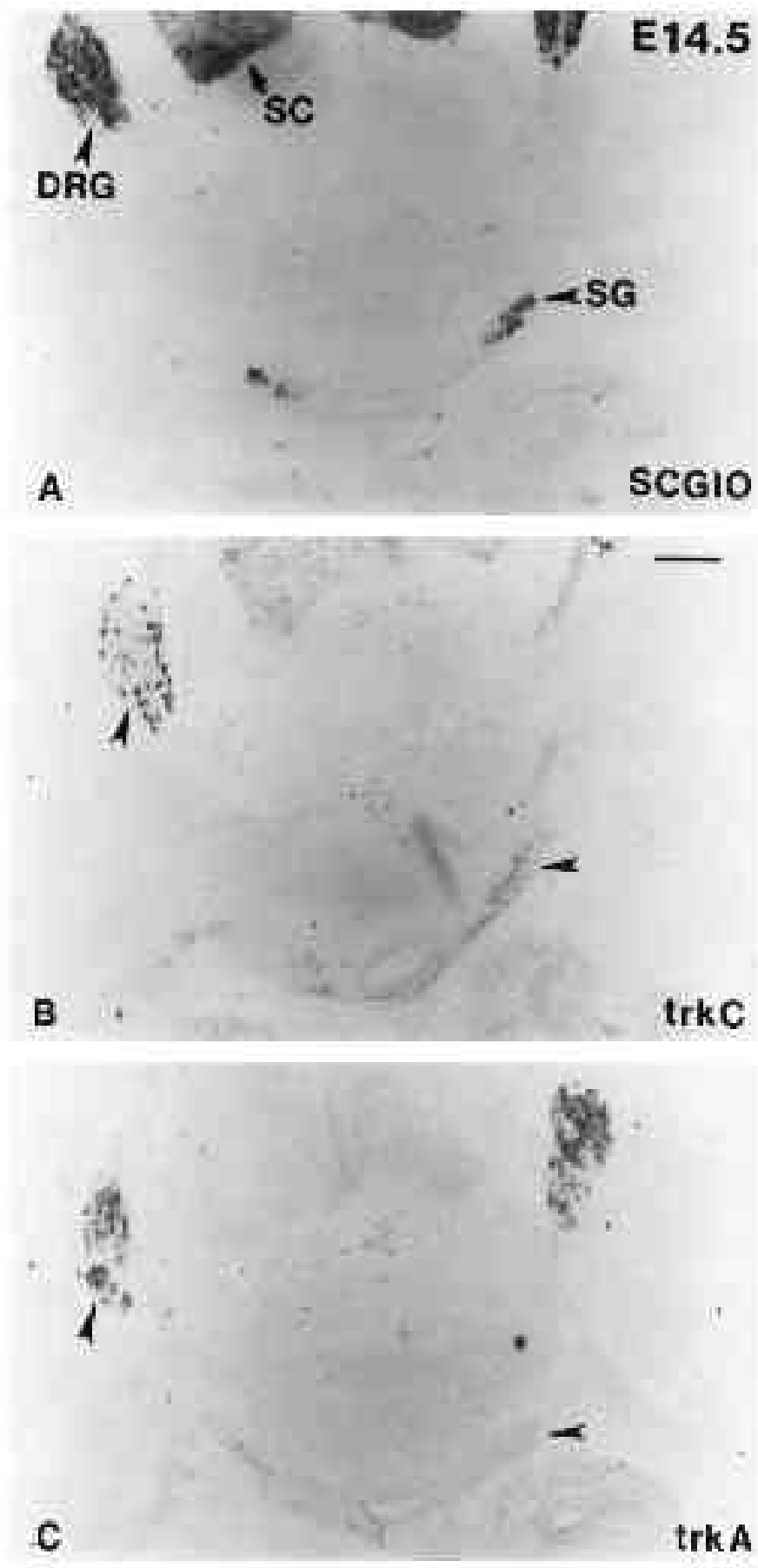

Fig. 1. E14.5 sympathetic ganglia express trkC but not trkA mRNAs. Nonradioactive in situ hybridization to consecutive serial transverse sections through the trunk region is shown, using the probes indicated on the panels. Note the location of the sympathetic ganglia (SG) revealed by SCG10 expression (A); these ganglia express trkC (B) but not trkA (C). The expression of trkC in sympathetic ganglia at this stage (B) is reproducibly lower than that observed in dorsal root ganglia (DRG) in the same sections (arrowhead, B). As previously reported (Martin-Zanca et al., 1990) trkA is abundantly expressed by dorsal root ganglia (DRG) neurons (compare A and C, upward arrowheads). Bar, 125 $\mu \mathrm{m}$. 
taining sufficient probe solution to immerse the part of the slides containing the sections. Probes used in this way could be re-used up to six or seven times without appreciable loss of signal. The anti-digoxigenin antibody (BMB) was preabsorbed with dissociated tissue from a mixture of fixed embryos from stages E12.5E13.5. The alkaline phosphatase reaction product was developed using the NBT/BCIP reagents. Sections were prewashed with levamisole, and development was carried out for 2-20 hours depending upon the abundance of the target mRNA. Wash buffers containing CHAPS detergent were re-used to economize. Probes used for in situ hybridization were: trkA, a 464 bp insert derived from the extracellular domain of the mouse trkA cDNA clone in plasmid pDM97; trkB, a 483 bp insert derived from the extracellular domain of the mouse trkB cDNA clone in plasmid pFRK16; trkC, an approx. $2 \mathrm{~kb}$ cDNA containing the extracellular and transmembrane domains in the plasmid pRtrkc8.

\section{RESULTS}

\section{Embryonic sympathetic neuroblasts express trkC but not trkA mRNA}

We sought to determine potential neurotrophic factors for sympathetic neuron precursors by examining the expression of neurotrophin receptor mRNAs in rat sympathetic ganglia
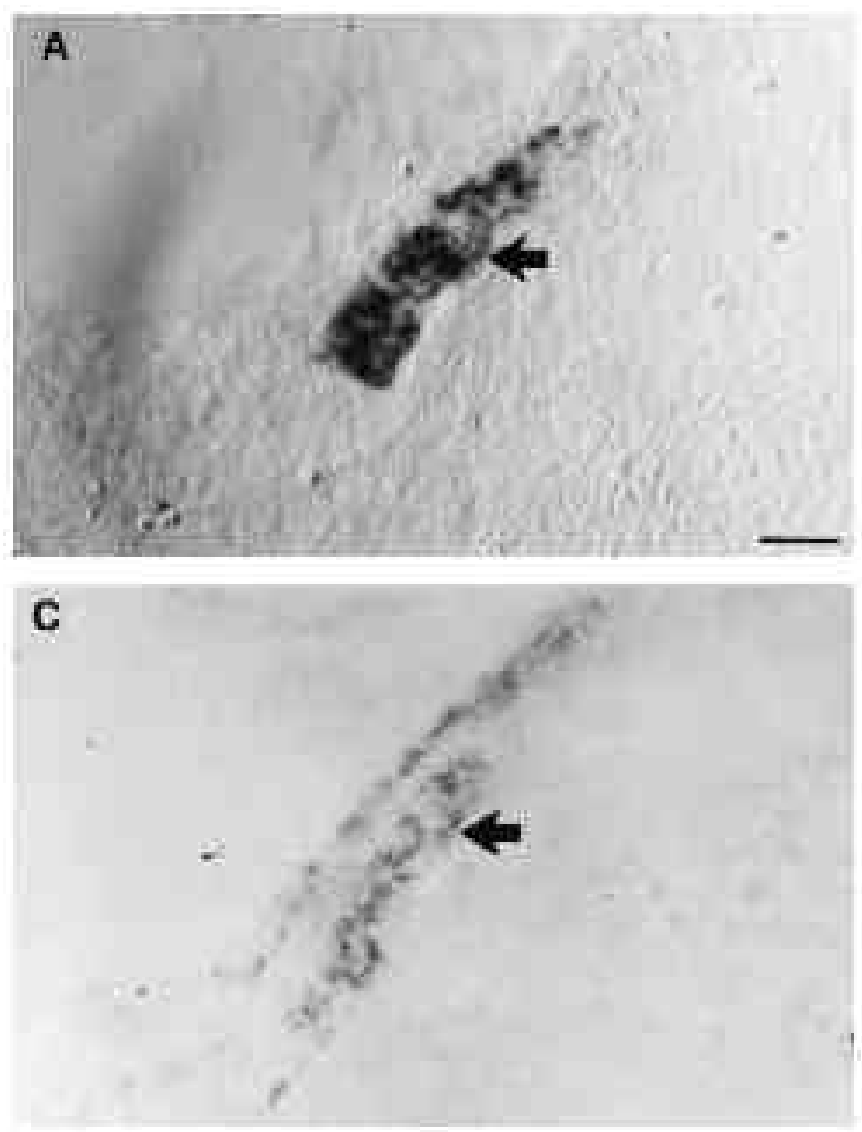

during embryonic development. Initially we assayed for the expression of trkA mRNA in embryonic day 14.5 (E14.5) rat sympathetic ganglia by non-radioactive in situ hybridization with a cRNA probe. As a positive control, adjacent serial sections were hybridized with a probe for SCG10, a pan-neuronal marker (Stein et al., 1988), to reveal the distribution of neuronal cell bodies in dorsal root and sympathetic ganglia (Fig. 1A). At this stage, the trkA probe did not hybridize to neuronal cells in the sympathetic ganglia, although trkA message was clearly detected in the DRG where it was resticted to large neuronal cell bodies (Fig. 1C).

Given that early sympathetic precursor cells do not express NGF receptor mRNA, we asked whether these cells express mRNAs encoding receptors for other neurotrophic factors. Neurotrophin 3 (NT-3) is a member of the neurotrophin family and is widely expressed in the periphery (Maisonpierre et al., 1990a) as well as in embryonic sympathetic ganglia (Schecterson and Bothwell, 1992). We therefore examined the expression of trkC, the NT-3 receptor. In contrast to trkA mRNA, trkC mRNA was clearly detectable in E14.5 sympathetic ganglia (Fig. 1B, arrowhead). Close comparison of the trkC and SCG10 expression patterns in adjacent serial sections, with the increased cellular resolution afforded by the non-radioactive
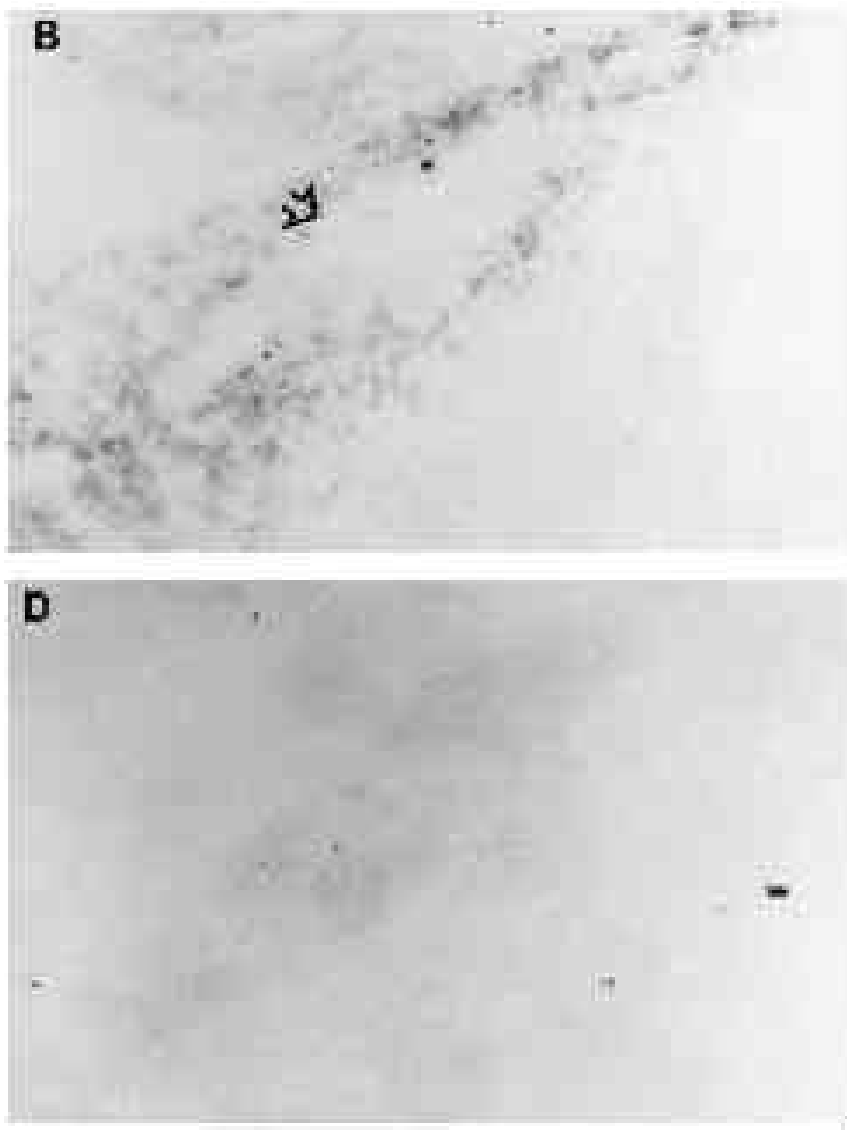

Fig. 2. Higher magnification view of neurotrophin receptor mRNA expression in E14.5 trunk sympathetic ganglia. Consecutive serial transverse sections hybridized with probes for SCG10 (A), trkB (B), trkC (C) and trkA (D) are shown. Note that the trkB-expressing cells exclude the region of the ganglion primordium occupied by SCG10-expressing neuroblasts (A, arrow; cf. B, open arrow). By contrast, trkC mRNA expression is detected within the SCG10-expressing region (C, arrow), as well as in a strip of cells in the adjacent mesenchyme. No expression of trkA mRNA is detected (D). Bar, $32 \mu \mathrm{m}$. 
technique, indicated that trkC was indeed expressed by neuroblasts in the developing ganglia (compare Fig. 2A and C), while trkA was not detected (Fig. 2D). We cannot exclude that trkC is also expressed in glial precursors, although it cannot be exclusively expressed in these cells as they have a different distribution in the ganglia from the neuroblasts (Guillemot et al., unpublished data). By contrast, the expression of trkB (previously reported in embryonic sympathetic ganglia, Schecterson and Bothwell, 1992) appeared restricted to non-neuronal cells circumscribing the condensing ganglionic neuroblasts (Fig. 2B). These cells may be mesenchymal cells or they may be glial precursors (Guillemot, et al., unpublished data). The specificity of our non-radioactive in situ hybridization procedure is demonstrated by the fact that four distinct probes gave four distinct expression patterns under our high-stringency annealing conditions.

\section{NT-3 but not NGF acts as a survival factor for isolated E14.5 sympathetic neuroblasts}

The expression pattern of neurotrophin receptor mRNAs in early rat sympathetic ganglia suggested that sympathetic precursor cells at this stage may respond to NT-3 but not to NGF. To test this hypothesis, we isolated an antigenically homogeneous population of sympathetic precursor cells from E14.5 rat embryos using a monoclonal antibody called B2, and examined its responsiveness to NGF and NT-3 in vitro. B2 detects a cell surface glycolipid (J. Dodd, personal communication) expressed specifically in most or all neuroblasts of sympathetic ganglia beginning at E13.5-E14.5, the time that progenitors in these ganglia commit to a neuronal fate (Anderson and Axel, 1986; Anderson et al., 1991). FACS isolation of $\mathrm{B} 2^{+}$cells from E14.5 embryos yielded a $92 \%$ pure population, as assessed by counterstaining with DAPI (Fig. 3A,B). In addition, $96 \%$ of isolated $\mathrm{B} 2^{+}$cells also expressed the tetanus toxin receptor on their surface (Fig. 3C,D), confirming that these cells exhibit a neuronal phenotype. Furthermore, $\mathrm{B} 2^{+}$cells when plated in defined, serum-free medium rapidly extend long, neurofilament-containing neurites in the absence of any added growth factors (Fig. 3E). These cells, however, lack the large cell bodies characteristic of mature sympathetic neurons and are still mitotically active (see below), indicating that they are not neurons, but rather neuroblasts. The properties of these cells are therefore similar to those of $\mathrm{B}^{+}$cells previously isolated from E14.5 adrenal glands (Anderson and Axel, 1986), and also resemble those of sympathetic neuroblasts from embryonic chick ganglia (Rohrer and Thoenen, 1987).

When purified E14.5 B2+ cells were plated in defined, serum-free medium in the absence of growth factors, the cells elaborated long neurites but showed poor survival (Fig. $4 \mathrm{~A}, \mathrm{Con})$. In the presence of NGF, cell recovery after 24 hours was not significantly different than in the control condition (Fig. 4A, NGF), consistent with our failure to detect trkA mRNA in these cells by in situ hybridization in vivo. When NT-3 was added to the growth medium at 25 $\mathrm{ng} / \mathrm{ml}$, however, a significant increase in cell recovery was seen (Fig. 4A,B, NT-3). In addition, the cells appeared healthier as judged by morphological criteria (not shown). Dose-response experiments (see below, Fig. 8B) indicated that half-maximal activity of NT-3 on these cells was obtained at $1 \mathrm{ng} / \mathrm{ml}$. In control medium, on average $35 \%$ cell recovery was obtained. Cell recovery continued to decline with longer incubations in control medium, suggesting that some cells simply take more time to die. However, some $\mathrm{E} 14.5 \mathrm{~B} 2^{+}$cells may survive for short periods independent of exogenous NT-3. Whether this reflects a true neurotrophin independence, or rather the production of endogenous neurotrophins by the cells, remains to be determined. In any case, at E14.5 a large proportion of sympathetic neuron precursor cells demonstrate a functional response to $\mathrm{NT}-3$, consistent with the detection of trkC mRNA in vivo by in situ hybridization. B2 ${ }^{+}$cells isolated at E15.5 also showed a response to NT-3 (not shown).

The increased number of sympathetic neuroblasts recovered in the presence of NT-3 raised the possibility that these cells may be dependent upon NT-3 for survival (see below). To determine whether these cells undergo apoptotic cell death in the absence of added growth factors, we examined the effect of aurintricarboxylic acid (ATA), which inhibits apoptotic cell death in sympathetic neurons and PC12 cells deprived of NGF (Batistatou and Greene, 1991). When $\mathrm{B}^{+}$cells were cultured in the presence of ATA, there was an increased recovery of cells after 24 hours even in the absence of NT-3 (Fig. 4B). The number of cells recovered after treatment with ATA was similar to that obtained with NT-3, suggesting that B2 ${ }^{+}$cells indeed are programmed to undergo apoptosis in the absence of growth factors.

Since E14.5 B2 + cells are mitotically active, NT-3 could act to increase the recovery of these cells in several different ways: it could act as a mitogen, as a survival factor, or as both. We therefore examined the effects of NT3 on the proliferation of E14.5 $\mathrm{B} 2^{+}$cells using a BrdUlabelling assay. We compared the effect of NT-3 to that of bFGF (basic fibroblast growth factor), a known mitogen for the sympathoadrenal lineage (Birren and Anderson, 1990; Claude et al., 1988; Stemple et al., 1988). While FGF stimulated BrdU incorporation (Fig. 5A), the percentage recovery of viable cells after 24 hours in this condition was not significantly different from control (Fig. 5B). This result is consistent with the idea that bFGF acts as a mitogen but not as a survival factor for sympathoadrenal lineage cells (Birren and Anderson, 1990; Stemple et al., 1988). When $\mathrm{B} 2^{+}$precursor cells were treated with NT-3, the stimulation of BrdU incorporation was similar to (or slightly lower than) that obtained with bFGF (Fig. 5A). However, these same NT-3-treated cultures showed a clear increase in the recovery of viable cells, in contrast to bFGF-treated or control cultures (Fig. 5B) (although the apparent magnitude of this increase was not as great as in other experiments, due to cell losses occurring during washes in the BrdU-labeling procedure).

These data suggest that the increased cell recovery obtained with NT-3 is unlikely to be explained by a purely mitogenic action, otherwise the percentage cell recovery would have been similar to that obtained with bFGF. While we cannot rule out a partial mitogenic activity for NT-3, our data suggest that this neurotrophin is also likely to act as a survival factor for B2+ cells. That the survival of these cells can be promoted independently of mitogenic stimulation is shown by the ability of ATA, which is not a mitogen, to promote increased recovery of the cells (see Fig. 4B, above). 

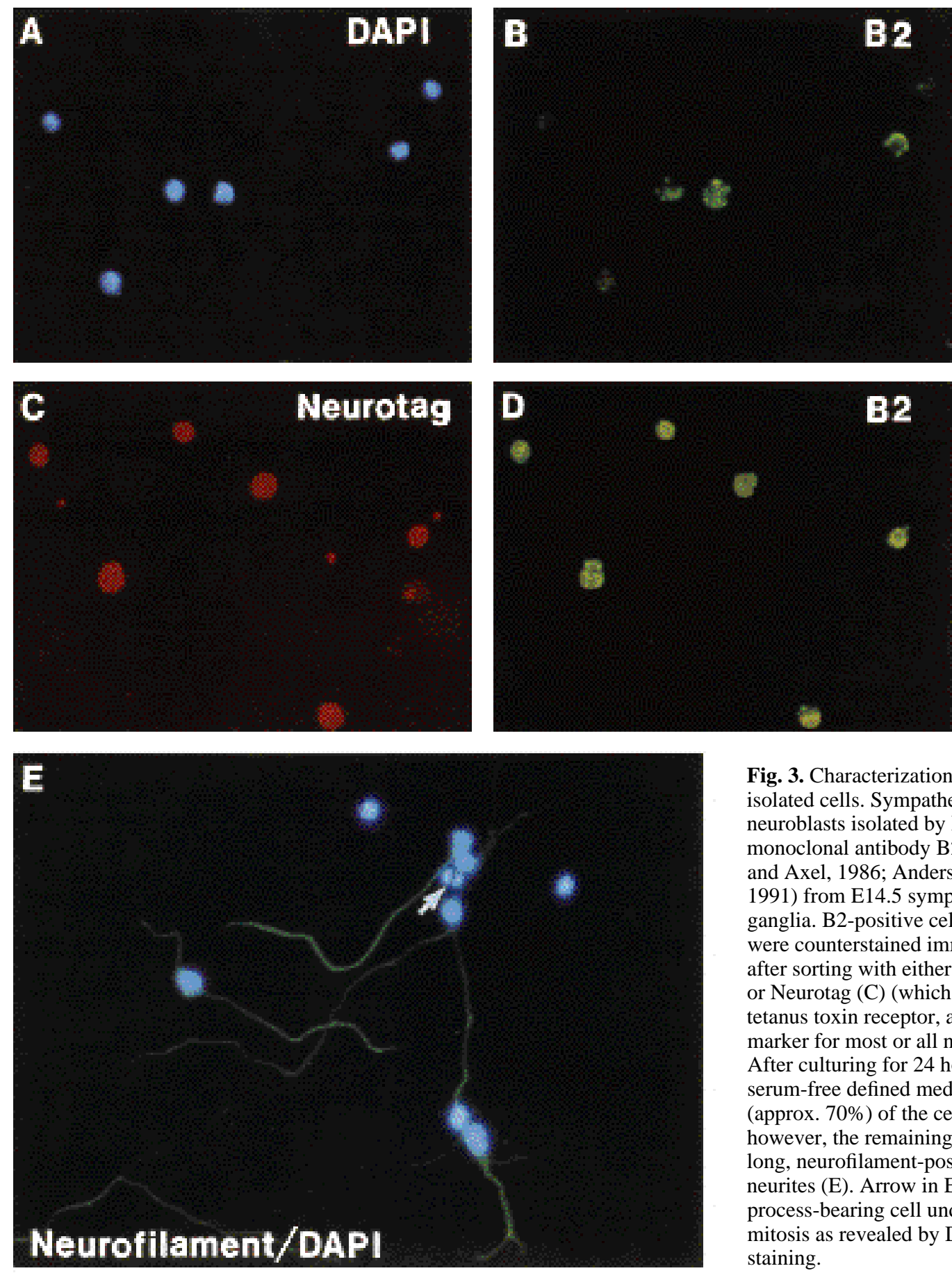

Fig. 3. Characterization of B2isolated cells. Sympathetic neuroblasts isolated by FACS using monoclonal antibody B2 (Anderson and Axel, 1986; Anderson et al., 1991) from E14.5 sympathetic ganglia. B2-positive cells (B,D) were counterstained immediately after sorting with either DAPI (A) or Neurotag $(\mathrm{C})$ (which detects the tetanus toxin receptor, a surface marker for most or all neurons). After culturing for 24 hours in serum-free defined medium, most (approx. 70\%) of the cells had died; however, the remaining cells bore long, neurofilament-positive neurites (E). Arrow in $\mathrm{E}$ indicates a process-bearing cell undergoing mitosis as revealed by DAPI staining.

Indeed, the apparent stimulation of BrdU incorporation by NT-3 (Fig. 5A) could reflect a purely trophic effect on a subpopulation of proliferating cells, rather than a mitogenic effect.

Further evidence for a trophic role for NT-3 comes from experiments in which cohorts of untreated or NT-3-treated $\mathrm{B} 2^{+}$precursors cells were identified at clonal density and then followed. After a 72 hour culture period, only $18 \%$ of control colonies had survived ( $\mathrm{n}=45$ colonies followed), while $40 \%$ of colonies in NT-3 had survived $(n=50$ colonies followed). (Overall survival in these experiments was reduced due to the low plating densities used for single cell tracking). If NT-3 were acting solely as a mitogen, then the number of colonies recovered in control and NT-3 should have been identical, but the colonies should have been larger in NT-3 (i.e., a larger percentage of colonies should have had $>1$ cell). However, as indicated above, colony recovery was clearly greater in the presence of the neurotrophin (although colony size was slightly greater as well). Moreover, while the majority of surviving cells divided at least once during the entire cohort experiment, only about half of the cells had divided once during the first 24 hours in the presence of NT-3. This extent of proliferation is insufficient to account for the two- to three-fold stimulation of 
A

E14.5 B2+ precursor cells

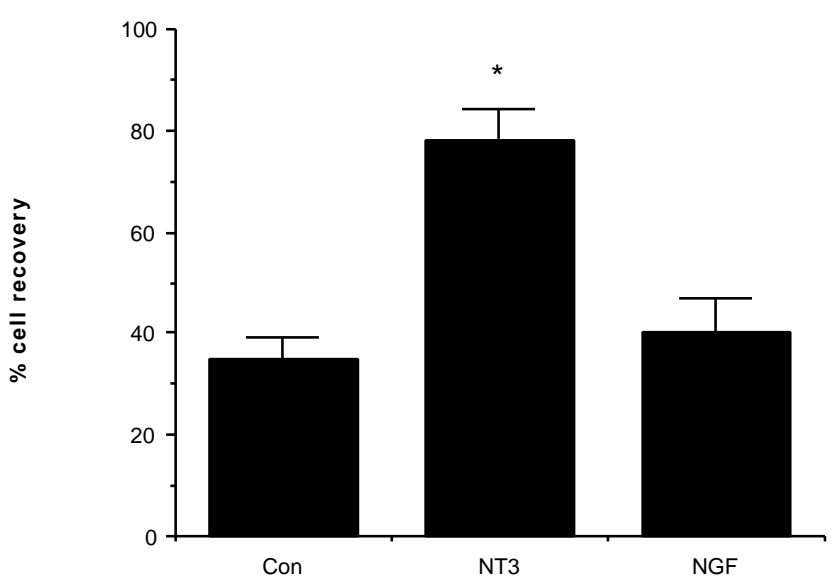

B

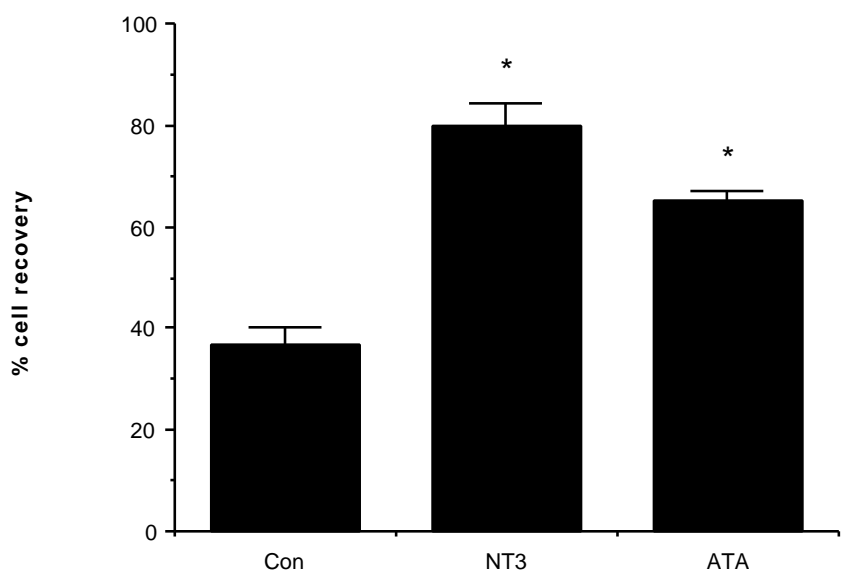

Fig. 4. E14.5 B2+ cells respond to NT-3. (A) The percentage cell recovery in the indicated conditions is calculated by normalizing the total number of cells recovered after 24 hours of culture to the starting number of cells in each culture (see Experimental Procedures). This normalization controls for well-to-well variations in the initial plating efficiency. The values plotted in (A) represent the mean $\pm \mathrm{s}$. e. $\mathrm{m}$. of the average of triplicate determinations from each of 4-8 independent experiments. For each determination, all of the cells were counted in a given well (typically 600-800 cells for NT-3 and 200-300 for control). This procedure eliminates the sampling error due to uneven cell distribution inherent in counting random microscopic fields or strips. Note that NT-3 but not NGF yields an increased cell recovery over control (asterisk indicates the difference is significant to $P \leq 0.05$ by Student's $t$-test). (B) One condition included $25 \mu \mathrm{M}$ aurintricarboxylic acid (ATA), an inhibitor of apoptotic cell death in sympathetic neurons and PC12 cells (Batistatou and Greene, 1991). Note that the percentage cell recovery in ATA is close to that obtained with NT-3. Bars represent the mean \pm s. e. $\mathrm{m}$. of two independent experiments, each with triplicate determinations. Asterisks indicate the NT-3 and ATA conditions are significantly different from control $(P \leq 0.05)$.

cell recovery promoted by NT-3 in mass culture experiments, again supporting the conclusion that NT-3 acts as a survival factor.
A

E14.5 B2+ precursor cells

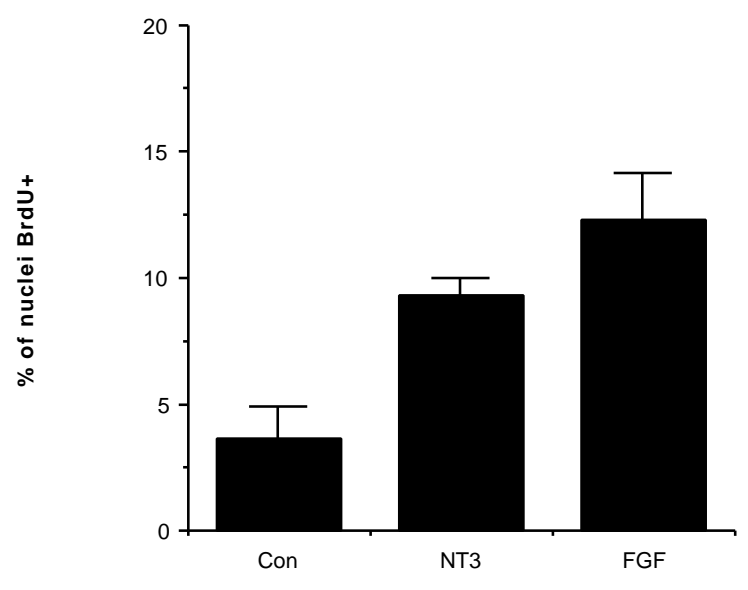

B

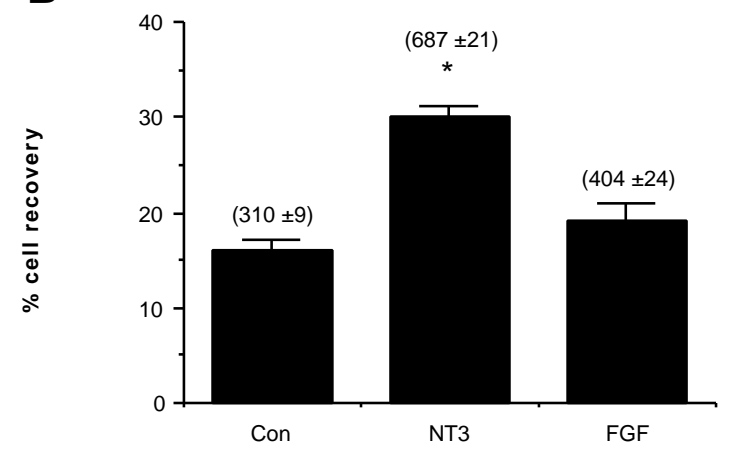

Fig. 5. NT-3 acts as a survival factor and not simply as a mitogen for E14.5 B2+ cells. (A) Cultures grown in the indicated factors were pulsed with BrdU for the final 8 hours of a 24 hour culture period and developed using an anti-BrdU antibody. The percentage of $\mathrm{DAPI}^{+}$nuclei labeled by BrdU was determined. The error bars represent the mean \pm s. e. $\mathrm{m}$. of triplicate determinations. (B) The percentage recovery of viable $\left(\mathrm{MTT}^{+}\right)$cells was measured in sister cultures and calculated for the cultures labeled with BrdU in A. (BrdU and MTT staining could not be performed on the same plates due to fixation incompatibility; see Experimental Procedures). The numbers in parentheses indicate the average total number of $\mathrm{MTT}^{+}$cells calculated for each condition; the bars represent this number normalized to the number of cells present 3 hours after plating. Note that NT-3 promotes higher cell recovery than bFGF (B) even though the latter is if anything a stronger mitogen (A). The apparent percentage cell recovery in all conditions is depressed in this experiment, because the extensive washings employed for BrdU labeling caused cell detachment. However, within this experiment, the relative effects of NT-3 and bFGF on viability versus BrdU incorporation should be directly comparable. Similar results were obtained in two independent repetitions of the experiment. Asterisk indicates the NT-3 condition is significantly different from control $(P \leq 0.5)$.

\section{Reciprocal regulation of neurotrophin responsiveness during sympathetic development}

E14.5 sympathetic neuroblasts express trkC mRNA and respond to NT-3; in contrast, neither trkA mRNA nor a biological response to NGF can be detected in these cells. 

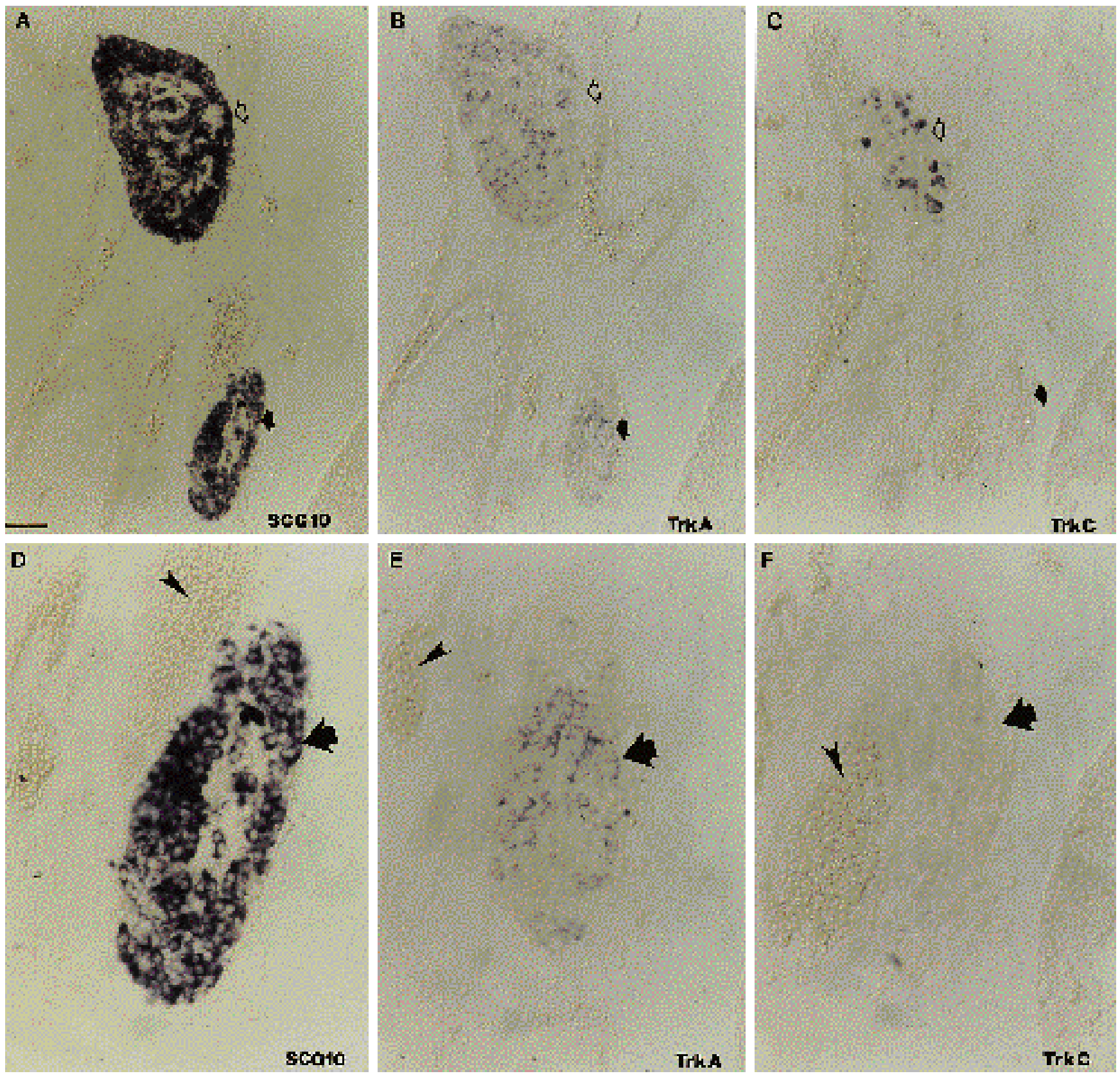

Fig. 6. Reciprocal regulation of trkC and trkA mRNAs during later sympathetic development. Consecutive serial transverse sections from the thoracic region of an E19.5 embryo were hybridized with probes for SCG10 (A,D), trkA (B,E) and trkC (C,F). Nonradioactive detection was employed to achieve increased cellular resolution. Open arrows (A-C) indicate DRG, solid arrows the sympathetic ganglia. (D-F) Higher magnification views of the sympathetic ganglia (solid arrows) shown in A-C, respectively. Arrowheads in D-F indicate blood vessels near the ganglia. Note that trkA but not trkC is expressed in the sympathetic ganglia; the DRG provide an internal positive control for trkC expression (C, open arrow). TrkA mRNA was first detectable in sympathetic ganglia at E16.5-17.5, a stage when trkC mRNA is still expressed (not shown). Bar (A-C), $110 \mu \mathrm{m}$; (D-F), $40 \mu \mathrm{m}$.

However, neonatal sympathetic neurons respond to, and are dependent upon, NGF for survival. This implies that sympathetic precursors must acquire the ability to respond to NGF during development. Furthermore, if mature sympathetic neurons are dependent solely upon NGF for survival, then either the cells must lose NT-3 responsiveness as they develop, or NT-3 must become unavailable to the mature cells. To examine changes in neurotrophin responsiveness of sympathetic precursor cells through development, we first followed the expression of trkA and trkC mRNAs in sympathetic ganglia by non-radioactive in situ hybridization at E15.5, E16.5, E17.5, E18.5 and E19.5. The results obtained from E15.5 embryos resembled those at E14.5, in that trkC mRNA was detectable but trkA mRNA was not (data not shown). Subsequent to E15.5, the relative levels of trkA and trkC mRNAs shifted dramatically. TrkA 
mRNA was occasionally detectable at E16.5 and, by E17.5, was readily apparent; by contrast trkC mRNA began to decline after E17.5 (data not shown). By E19.5, the expression of trkC mRNA was below the limit of detection (Fig. 6C,F), while trkA mRNA was clearly detectable (Fig. $6 \mathrm{~B}, \mathrm{E})$. Thus, trkA and trkC mRNAs show reciprocal but overlapping patterns of expression in developing sympathetic ganglia, suggesting that there may be a switch in neurotrophin responsiveness during sympathetic neuron differentiation. Others have reported recently on the expression of trk mRNAs in developing rodent embryos (Martin-Zanca et al., 1990; Ernfors et al., 1992; Klein et al., 1990; Schecterson and Bothwell, 1992), but the stages analyzed were not appropriate to observe the reciprocal regulation of trkA and trkC mRNAs in sympathetic ganglia.

To correlate the changes in trkA and trkC mRNA expression with the neurotrophin responsiveness of sympathetic neuroblasts, B2 ${ }^{+}$cells were isolated from E19.5 sympathetic ganglia and their responsiveness to NGF and NT-3 compared in vitro. By contrast to the results at E14.5 (Fig. 4A), NGF clearly increased the recovery of E19.5 B2 ${ }^{+}$ cells in a 24 hour assay (Fig. 7A) (although $100 \%$ cell recovery was not obtained, suggesting that some $\mathrm{B} 2^{+}$cells may not yet be NGF responsive). These cells were also supported to some extent by NT-3 (Fig. 7A); however, the percentage cell recovery obtained was smaller at E19.5 than at E14.5 (compare Fig. 7A and Fig. 4A, NT-3). These data therefore confirm that the appearance of trkA mRNA, as detected by in situ hybridization, is correlated with the appearance of a biological response to NGF in isolated sympathetic neuroblasts assayed at the same stage in vitro. While a complementary decline in trkC mRNA expression is observed, a relatively modest diminution in the responsiveness of the $\mathrm{B} 2^{+}$cell population to NT-3 is apparent at the saturating concentrations of neurotrophin used (but see below).

To examine the effects of NGF and NT-3 on a more mature population of sympathetic neurons, we used dissociated cultures of neonatal superior cervical sympathetic ganglia (SCG). Monoclonal antibody B2 could not be used to isolate these cells, however, as the expression of this antigen has declined by this stage (Anderson et al., 1991). As expected from previous studies (Chun and Patterson, 1977; Levi-Montalcini and Angeletti, 1963), NGF was sufficient to support the survival of most neonatal SCG neurons, even in our serum-free medium (Fig. 7B). By contrast, NT-3 at $25 \mathrm{ng} / \mathrm{ml}$ had only a weak survivalpromoting effect (Fig. 7B). It supported less than half as many neurons as did NGF, whereas in the E19.5 B2+ cultures NT-3 supported almost as many cells as supported by NGF. Moreover, the percentage recovery of neonatal SCG neurons supported by NT-3 was significantly less than the percentage recovery of E19.5 B2+ cells supported by the factor (compare Fig. 7A and B, NT-3). The fact that $60-70 \%$ of neonatal SCG neurons could be supported by NGF indicates that the low cell recovery in NT-3 is not due simply to lowered overall cell viability at this later age.

These data suggest that the responsiveness of sympathetic neurons to NT-3 indeed declines with development, consistent with the down-regulation of trkC mRNA observed in
A

E19.5 B2+ precursor cells

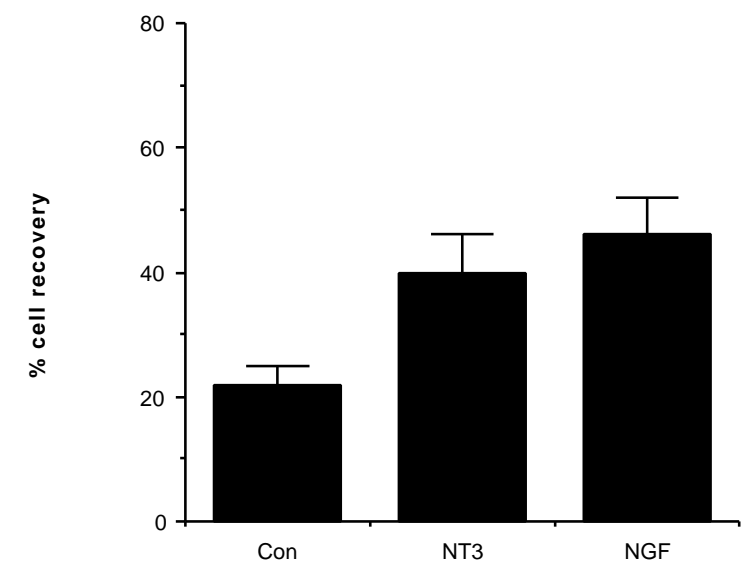

B

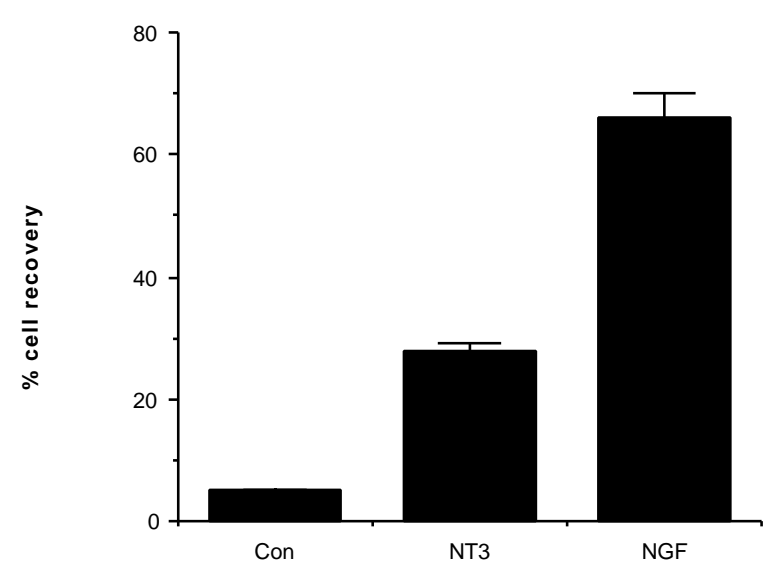

Fig. 7. Sympathetic neurons are NGF responsive at E19.5. (A) Cell recovery assays were performed as described in Fig. 4 on E19.5 B2 ${ }^{+}$cells, using $25 \mathrm{ng} / \mathrm{ml}$ each of NGF and NT-3. Note that equal or greater cell recovery is obtained with NGF than NT-3, and that the percentage cell recovery obtained with NT-3 at E19.5 is less than that obtained using NT-3 with E14.5 B2+ cells (compare with Fig. 4A and B, NT-3). (B) Cell recovery assays were performed using neonatal SCG neurons in dissociated culture, grown exactly as described for $\mathrm{B} 2{ }^{+}$cells except that recovery was assayed after 48 hours. Note that the effect of NT-3, both in relation to NGF and in absolute terms, is weaker than observed for E19.5 cells (A). The experiments in A and B were performed three times with similar results.

vivo. One apparent inconsistency with this conclusion is that the fold-stimulation over control obtained with NT-3 was higher for the neonatal SCG population than for the E19.5 $\mathrm{B}^{+}$population. However, this difference reflects a higher baseline survival of the E19.5 cells under control conditions (compare Figs. 7A and B, Con), suggesting that this less mature population, like that obtained from E14.5 embryos (see above) contains some cells that can survive for short periods in the absence of exogenous NT-3. 


\section{Early and late sympathetic neurons exhibit distinct dosage sensitivities to NT-3}

In the foregoing experiments, the responsiveness of developing sympathetic neuroblasts to NT-3 was examined at high concentrations of the factor, as in previous studies (Ernfors et al., 1990; Maisonpierre et al., 1990b; Rosenthal et al., 1990). Given that these neurons do not express detectable trkC mRNA in vivo, their response to the neurotrophin in vitro therefore could be a cross-reactivity of NT-3 with a receptor other than trkC (Cordon-Cardo et al., 1991; Glass et al., 1991; Soppet et al., 1991). Alternatively, a subpopulation of SCG neurons could express trkC, or reexpress it under our culture conditions. As a first step to address this issue, we investigated the dose-response properties of NT-3 on the survival of neonatal SCG neurons (Fig. 8A). Two main findings emerged from this analysis: first, the concentration of NT-3 used in the preceding experiments $(25 \mathrm{ng} / \mathrm{ml})$ is subsaturating; second, the dose-response curve for NT-3 was shifted to the right relative to the profile for NGF. The concentration of NT-3 required for a halfmaximal response $\left(\mathrm{EC}_{50}\right)$ was $1.1 \times 10^{-9} \mathrm{M}$, as compared to $3.2 \times 10^{-12} \mathrm{M}$ for NGF, a 340-fold difference. The high $\mathrm{EC}_{50}$ for NT-3, as well as the failure to achieve saturating responses at doses of $10-25 \mathrm{ng} / \mathrm{ml}$, suggested that this neurotrophin may be acting on neonatal SCG neurons through a receptor distinct from trkC. (By contrast, if the SCG cultures contained a subpopulation of trkC-expressing neurons, one would have expected to see a dose-response profile that saturated at $1-10 \mathrm{ng} / \mathrm{ml}$ of NT-3, but which supported many fewer neurons than NGF even at saturation; this was not observed).

To determine whether immature sympathetic neuroblasts were more sensitive to NT-3, we performed parallel doseresponse experiments using E14.5 B2 ${ }^{+}$cells. In contrast to the results obtained with neonatal SCG neurons (see above), the concentration of NT-3 required for a half maximal functional response was $3.2 \times 10^{-11} \mathrm{M}$ (Fig. 8B). This value is close to the $\mathrm{EC}_{50}$ for NT-3 measured in trkC-transfected fibroblasts or PC12 cells (see, for example, Ip et al., 1993), and is consistent with our detection of trkC mRNA in E14.5 sympathetic ganglia by in situ hybridization. In turn, the 34fold higher $\mathrm{EC}_{50}$ that we observe for NT-3 on neonatal SCG neurons suggests that the NT-3 response is mediated in these more mature neurons by a receptor other than trkC, perhaps trkA (Cordon-Cardo et al., 1991). It should be noted that this low functional dosage sensitivity does not necessarily indicate the presence of receptors with a low binding affinity for NT-3, as suggested by recent studies of E11 chick sympathetic neurons (Dechant et al., 1993). Whatever the nature of the NT-3 receptors on these more mature cells, our data clearly demonstrate a developmental decline in the NT-3 sensitivity of freshly isolated rat sympathetic neurons and their precursors, which is well-correlated with a corresponding decline in the expression of trkC mRNA by these cells in vivo.

\section{DISCUSSION}

A central tenet of developmental neurobiology is that neuronal number is controlled by neurotrophic factors
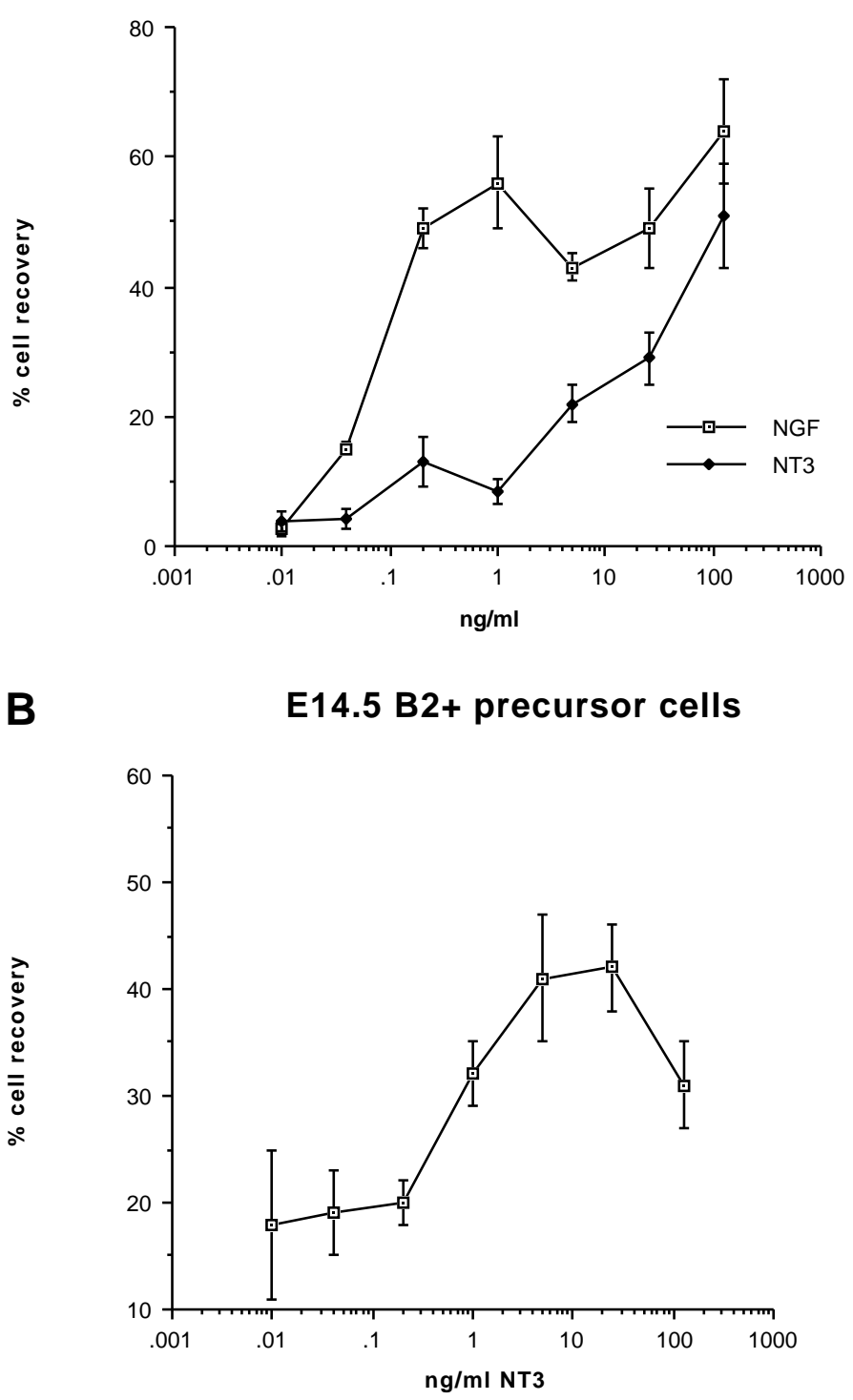

Fig. 8. Dose-response characteristics of NT-3 on neonatal and E14.5 sympathetic neurons. Cell recovery assays were performed as described above for neonatal SCG neurons (A) and E14.5 sympathetic neuroblasts (B), using NT-3 or NGF. The data points represent the mean \pm s. e. $\mathrm{m}$. of six determinations pooled from two independent experiments. Note that saturating responses to NT-3 in neonatal SCG cultures require over $200 \mathrm{ng} / \mathrm{ml}$ of factor. The $\mathrm{EC}_{50}$ for NT-3 in A is $1.1 \times 10^{-9} \mathrm{M}$, and in $\mathrm{B}$ is $3.2 \times 10^{-11} \mathrm{M}$. The $\mathrm{EC}_{50}$ for NGF in A is $3.2 \times 10^{-12} \mathrm{M}$. NGF dose-response profiles were not performed for E14.5 cells because no response to NGF was obtained even with saturating concentrations of the factor (Fig. 4A).

primarily at the stage when these cells are postmitotic, and have begun to innervate their targets (Purves and Lichtman, 1985). Here we have shown that mitotically active sympathetic neuroblasts immuno-isolated from early embryos require NT-3 for survival in a serum-free defined medium. At this stage, the cells do not respond to NGF. Later, the neuroblasts become progressively less responsive to NT-3 


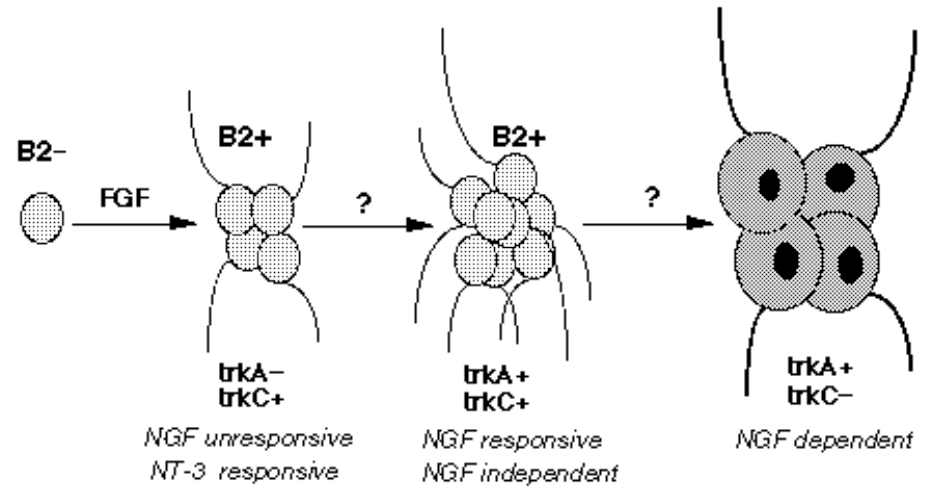

Fig. 9. Schematic summarizing the action of growth factors at different stages of sympathoadrenal development. Sympathetic neuroblasts are initially NGF unresponsive because they do not express trkA. When these cells initially express trkA, they become NGF responsive, but are not yet NGF dependent because they continue to express receptors for NT-3 (and perhaps other survival factors such as IGF-I). The cells only become NGF dependent when they lose receptors for trkC. FGF acts to promote neurite outgrowth and proliferation, but does not support cell survival in this lineage. We have not yet determined whether NT-3 acts as a survival factor for sympathoadrenal progenitors prior to the expression of the B2 antigen. The factors, if any, that promote the transitions between these different cell states are not known. and gain NGF dependence. This change in neurotrophin responsiveness in vitro is correlated with a reciprocal switch in neurotrophin receptor mRNA expression in vivo: E14.5 neuroblasts express trkC but not trkA mRNA, while E19.5 neuroblasts express trkA but not trkC mRNAs. Taken together, these data suggest that neurotrophic factors may control the number of neurons not only at the time of target field innervation, as previously thought, but also at earlier stages of development when these cells are mitotically active. A corollary to this idea is that the final acquisition of NGF dependence involves a change in the factor that supports cell survival, not necessarily a transition from a neurotrophin-independent to a neurotrophin-dependent neuron, as originally believed. While it is possible that sympathetic precursors at yet earlier stages are neurotrophin independent (as reported in chick; see Dechant et al., 1993; Ernsberger et al., 1989), this model fits well with the recently expressed idea that many, if not all, cells require trophic support at all times and that programmed cell death occurs far more extensively during development than previously appreciated (Raff, 1992).

\section{Mitogens and trophic factors control sequential and overlapping stages in sympathetic development}

Previous studies of normal and immortalized rat sympathoadrenal lineage cells have indicated that these cells are responsive to FGF before they become responsive to NGF (Stemple et al., 1988; Birren and Anderson, 1990). FGF acts as both as a differentiation factor, promoting neurite outgrowth, and as a mitogen for these cells. The B2+ sympathetic neuroblasts that we have examined in the present experiments are already neurite bearing at the time of their isolation, and therefore do not require FGF for this aspect of differentiation. Nevertheless these cells continue to respond to FGF as a strong mitogen (Fig. 5). Despite this proliferation-promoting activity, however, FGF does not act as a survival factor for these $\mathrm{B} 2^{+}$cells, nor for sympathoadrenal progenitors at earlier developmental stages (Birren and Anderson, 1990; S. Birren, unpublished data). Studies of FGF protein (Kalcheim and Neufeld, 1990) and mRNA (D. Stemple and D. Anderson, unpublished) expression in vivo indicate that this factor is present at a place and time appropriate for a role in normal sympathetic development.

$\mathrm{B} 2^{+}$cells that respond to FGF also respond to NT-3. By contrast to FGF, however, NT-3 acts primarily as a survival factor for these neuroblasts, although it may also have mitogenic effects. A partial mitogenic action for NT-3 would be consistent with a similar action for this factor on trkC-transfected fibroblasts (Cordon-Cardo et al., 1991). Studies of NT-3 mRNA expression by in situ hybridization have revealed that this gene is expressed in rodent sympathetic ganglia at stages of development comparable to those analyzed here (Schecterson and Bothwell, 1992), possibly in the ganglionic neurons themselves. Such observations are consistent with an autocrine or paracrine action for this neurotrophin in this context. By contrast, NGF is synthesized primarily by targets of sympathetic innervation (Davies et al., 1987; Korsching and Thoenen, 1988). By the time that sympathetic neurons innervate their targets they are postmitotic, so that NGF does not exert a mitogenic effect on these cells. However, NGF can act as a mitogen for other proliferative cells in the sympathoadrenal lineage, such as chromaffin cells (Lillien and Claude, 1985) and trkA-transfected MAH cells (Verdi et al., unpublished data). Taken together, these data support a model in which growth factors and neurotrophins control sequential and overlapping stages in sympathetic development, with FGF and NT-3 acting locally within developing ganglia to promote proliferation/differentiation and survival, respectively; and NGF acting as the ultimate target-derived trophic factor (Fig. 9). The overlapping but distinct effects of these factors on these cells in part reflects different response pathways at a given stage of development, and in part developmental changes in a given response pathway.

Other polypeptide factors have been shown to influence sympathetic neuroblasts at developmental stages comparable to those investigated here (for review, see Rohrer, 1990). Both insulin-like growth factor-I (IGF-I) and insulin have been shown to promote thymidine incorporation by proliferating sympathetic neuroblasts (DiCicco-Bloom and Black, 1988, 1989; DiCicco-Bloom et al., 1990). A similar effect has been observed for vasoactive intestinal polypeptide (VIP), a neuropeptide synthesized by some sympathetic neurons (Pincus et al., 1990). Since, in these studies, cell survival was not examined independent of proliferative activity, it is difficult to determine whether these factors indeed act as mitogens, as originally proposed, or whether they act as survival factors selective for proliferating cells. In our system, IGF-I and insulin also promoted cell recovery, although not as efficiently as NT-3 (data not shown). The presence of these factors in serum could 
account for the apparent neurotrophin independence of embryonic sympathetic neurons observed in previous studies (Coughlin and Collins, 1985). Recent studies of postmitotic chick sympathetic neurons indicated a survival effect of IGF-I on these cells (H. Rohrer (1993), Soc. Neurosci. Abstr.). Although the expression of IGF-I and its receptors in developing sympathetic ganglia have not been examined in detail, these data raise the possibility that not only NT-3, but also IGF-I, may act as interim survival factors for sympathetic neuroblasts. If so, then by analogy to our results with NT-3 and trkC, the expression of either IGF-I or its receptor should be down-regulated during sympathetic development to permit predominant control of neuronal survival by target-derived NGF.

\section{Why have a switch in neurotrophin receptor expression during development?}

Why should developing sympathetic neuroblasts undergo a developmental switch in neurotrophin responsiveness? If the ultimate function of neurotrophins is to act as target-derived survival factors, then at some point developing neurons must become dependent upon these factors for their survival. Although such a dependence could be held in abeyance until the neurons reach their targets (Coughlin and Collins, 1985; Ernsberger et al., 1989; Vogel and Davies, 1991), another strategy would be to express a trophic dependence constitutively, but have a different factor support survival until the target is reached. In that case, in order to achieve predominant control of neuronal survival by the target-derived neurotrophin, either the neurons must lose access to the interim survival factor or they must lose the ability to respond to it. Our data demonstrating a down-regulation of trkC mRNA coincident with the appearance of trkA mRNA are consistent with the latter explanation, and provide one rationale for the switch in neurotrophin receptor expression observed. Another explanation, which we have not formally excluded, is that the trkC-expressing neurons die and are replaced by trkA-expressing cells. (However, our E19.5 in vitro data suggests there is at least some overlap between NT-3reponsive and NGF-responsive cells). Whatever the explanation, the data raise the question of whether the reciprocal expression of trkC and trkA is controlled autonomously or non-autonomously and, if the latter, what environmental factors are involved.

\section{Early actions for neurotrophins during neuronal development}

Our data add to a growing body of evidence suggesting that the actions of neurotrophins are not restricted to target control of neuronal survival, but extend to earlier stages of neural development as well. Both NT-3 and BDNF have been shown to act on undifferentiated avian neural crest cells in vitro: the former as a mitogen (Kalcheim et al., 1992); the latter as a possible instructive signal for sensory neuron differentiation (Sieber-Blum, 1991). Dechant et al. (1993) recently reported that some E7 chick sympathetic neurons developed a response to NT-3 after 7 days in vitro (although freshly isolated E7 neurons did not respond to low concentrations of the neurotrophin). BDNF and NT-3 have been shown to act on progenitor cells in the developing cerebellum (Segal et al., 1992) and hippocampus (Collazo et al.,
1992), as assessed by increased cell recovery in dissociated cultures and induction of c-fos immunoreactivity in cultured slices. However, the precise biological action (mitogen, survival factor) of these factors was not assessed in these studies, nor was the distribution of receptor expression examined in vivo. Nevertheless these studies collectively raised the notion that neurotrophins do not act simply as survival factors for differentiated, postmitotic neurons, but also act on proliferating neuroepithelial progenitor cells as well. The idea that a given growth factor may exert different actions on developing cells at different stages in a given lineage is well accepted in the field of hematopoiesis, from studies of factors such as erythropoietin (Metcalf, 1989).

Our results also support the general concept that different members of the neurotrophin family may act at different stages within a given neurogenic lineage. The culture experiments mentioned above suggested a sequential action of NT-3 and BDNF in cerebellar granule cell development (Segal et al., 1992). Studies of cultured avian sensory neurons have revealed that the maturation of these postmitotic cells is promoted by BDNF (and possibly NT-3) before they become NGF dependent, although the former apparently do not act as survival factors (Wright et al., 1992). While we have also examined a possible role for BDNF, the results are less compelling: trkB mRNA was not expressed in ganglionic neuroblasts in vivo, and BDNF had only weak and irreproducible effects on the recovery of E14.5 B2 ${ }^{+}$cells in vitro (data not shown). Our data support a sequential action for NT-3 and NGF as survival factors in sympathetic neuron development, and further suggest that a progressive loss of NT-3 sensitivity may occur as NGF responsiveness is acquired.

Our dose-response data indicate that neonatal rat sympathetic neurons are far less sensitive to NT-3 than their embryonic precursors. The $\mathrm{EC}_{50}$ for NT-3 is similar to that recently reported for E11 chick sympathetic neurons (Dechant et al., 1993). These data may explain why some previous assays, utilizing high concentrations of the factor (approx. $60 \mathrm{ng} / \mathrm{ml}$ ), detected responses in embryonic chick sympathetic neurons (Ernfors et al., 1990; Maisonpierre et al., 1990b; Rosenthal et al., 1990), whereas others utilizing low concentrations (approx. $1 \mathrm{ng} / \mathrm{ml}$ ) did not (Hohn et al., 1990). Beyond reconciling these discrepancies, our data suggest that unless very high concentrations of NT-3 are achieved in vivo, the contribution of this factor to the trophic support of neonatal sympathetic neurons may be negligible. On the other hand, during prenatal development, NT-3 may play a crucial role in controlling neuroblast number locally in developing ganglia, before the neurons become dependent upon target-derived NGF (Schecterson and Bothwell, 1992). Definitive tests of the relative trophic influences of NT-3 and NGF at different developmental stages are now possible, in principle, through gene knockout experiments in the mouse.

We thank Pantelis Tsouflas and Luis Parada for providing trkA, trkB and trkC probes, George Yancopoulos for providing recombinant NT-3, Pat Cohen and Rochelle Diamond for help with cell sorting and members of the Anderson laboratory for their constructive suggestions during the course of this work. We are grateful to Jane Dodd for advice on non-radioactive in situ hybridization and for providing monoclonal antibody B2. We also thank Andrew Groves, Mahendra Rao and Paul Patterson for their critical 
comments on the manuscript. This work was supported by NIH grant NS23476 and by a PEW Faculty Fellowship in Neuroscience. D. J. A. is an Associate Investigator of the Howard Hughes Medical Institute.

\section{REFERENCES}

Anderson, D. J. and Axel, R. (1986). A bipotential neuroendocrine precursor whose choice of cell fate is determined by NGF and glucocorticoids. Cell 47, 1079-1090.

Anderson, D. J., Carnahan, J., Michelsohn, A. and Patterson, P. H. (1991). Antibody markers identify a common progenitor to sympathetic neurons and chromaffin cells in vivo, and reveal the timing of committment to neuronal differentiation in the sympathoadrenal lineage. J. Neurosci. 11, 3507-3519.

Angeletti, P. U., Levi-Montalcini, R. and Caramia, F. (1971). Ultrastructural changes in sympathetic neurons of newborn and adult mice treated with nerve growth factor. J. Ultrastruct. Res. 36, 24-36.

Barres, B. A., Hart, I. K., Coles, H. S. R., Burne, J. F., Voyvodic, J. T., Richardson, W. D. and Raff, M. C. (1992). Cell death and control of cell survival in the oligodendrocyte lineage. Cell 70, 31046.

Batistatou, A. and Greene, L. A. (1991). Aurintricarboxylic acid rescues PC12 cells and sympathetic neurons from cell death caused by nerve growth factor deprivation: Correlation with suppression of endonuclease activity. J. Cell Biol. 115, 461-471.

Birren, S. J. and Anderson, D. J. (1990). A v-myc-immortalized sympathoadrenal progenitor cell line in which neuronal differentiation is initiated by FGF but not NGF. Neuron 4, 189-201.

Bothwell, M. (1991). Keeping track of neurotrophin receptors. Cell 65, $915-$ 918.

Chun, L. L. Y. and Patterson, P. H. (1977). Role of nerve growth factor in the development of rat sympathetic neurons in vitro. J. Cell Biol.75, 694704.

Claude, P., Parada, I. M., Gordon, K. A., D'Amore, P. A. and Wagner, J. A. (1988). Acidic fibroblast growth factor stimulates adrenal chromaffin cells to proliferate and to extend neurites, but is not a longterm survival factor. Neuron 1, 783-790.

Collazo, D., Takahashi, H. and McKay, R. D. G. (1992). Cellular targets and trophic functions of neurotrophin-3 in the developing rat hippocampus. Neuron 9, 643-656.

Cordon-Cardo, C., Tapley, P., Jing, S., Nanduri, V., O'Rourke, E., Lamballe, F., Kovary, K., Klein, R., Jones, K. R., Reichardt, L. F. and Barbacid, M. (1991). The trk tyrosine protein kinase mediates the mitogenic properties of nerve growth factor and neurotrophin-3. Cell 66, 173-183.

Coughlin, M. D. and Collins, M. D. (1985). Nerve growth factorindependent development of embryonic mouse sympathetic neurons in dissociated cell culture. Dev. Biol. 110, 392-401.

Cowan, W. M., Fawcett, J. W., O'Leary, D. D. M. and Stanfield, B. B. (1984). Regressive events in neurogenesis. Science 225, 1258-1265.

Davies, A. M., Bandtlow, C., Heumann, R., Korsching, S., Rohrer, H. and Thoenen, H. (1987). The site and timing of nerve growth factor (NGF) synthesis in developing skin in relation to its innervation by sensory neurons and their expression of NGF receptors. Nature 326, 353358.

Dechant, G., Rodríguez-Tébar, A., Kolbeck, R. and Barde, Y.-A. (1993). Specific high-affinity receptors for Neurotrophin-3 on sympathetic neurons. J. Neurosci. 13, 2610-2616.

DiCicco-Bloom, E. and Black, I. B. (1988). Insulin growth factors regulate the mitotic cycle in cultured rat sympathetic neuroblasts. Proc. Natl. Acad. Sci. USA 85, 4066-4070.

DiCicco-Bloom, E. and Black, I. B. (1989). Depolarization and insulin-like growth factor-I (IGF-I) differentially regulate the mitotic cycle in cultured rat sympathetic neuroblasts. Brain Res 491, 403-406.

DiCicco-Bloom, E., Townes-Anderson, E. and Black, I. B. (1990). Neuroblast mitosis in dissociated culture: regulation and relationship to differentiation. J. Cell Biol. 110, 2073-2086.

Ellis, R. E., Yuan, J. and Horvitz, H. R. (1991). Mechanisms and functions of cell death. Annu. Rev. Cell Biol.7, 663-698.

Ernfors, P., Ibáñez, C. F., Ebendal, T., Olson, L. and Persson, H. (1990). Molecular cloning and neurotrophic activities of a protein with structural similarities to nerve growth factor: Developmental and topographic expression in the brain. Proc. Natl. Acad. Sci. USA 87, 54545458.

Ernfors, P., Merlio, J.-P. and Persson, H. (1992). Cells expressing mRNA for neurotrophins and their receptors during embryonic rat development. Eur. J. Neurosci. 4, 1140-1158.

Ernsberger, U., Edgar, D. and Rohrer, H. (1989). The survival of early chick sympathetic neurons in vitro is dependent on a suitable substrate but independent of NGF. Dev. Biol 135, 250-262.

Glass, D. J., Nye, S. H., Hantzopoulos, P., Macchi, M. J., Squinton, S. P., Goldfarb, M. and Yancopoulos, G. D. (1991). TrkB mediates BDNF/NT-3 dependent survival and proliferation in fibroblasts lacking the low affinity NGF receptor. Cell 66, 405-413.

Hamburger, V., Brunso-Bechtold, J. K. and Yip, J. W. (1981). Neuronal death in the spinal ganglia of the chick embryo and its reduction by nerve growth factor. J. Neurosci. 1, 60-71.

Harland, R. M. (1991). In situ hybridization: an improved whole mount method for Xenopus embryos. In Methods in Cell Biology (ed. B. K. Kay and H. J. Peng). Vol. 36. pp. 675-685. New York: Academic Press.

Hawrot, E. and Patterson, P. H. (1979). Long-term culture of dissociated sympathetic neurons. Methods in Enzymology 58, 574-583.

Hohn, A., Leibrock, J., Bailey, K. and Barde, Y.-A. (1990). Identification and characterization of a novel member of the nerve growth factor/brainderived growth factor family. Nature 344, 339-341.

Ip, N. Y., Stitt, T. N., Tapley, P., Klein, R., Glass, D. J., Fandl, J., Greene, L. A., Barbacid, M. and Yancopoulos, G. D. (1993). Similarities and differences in the way neurotrophins interact with the Trk receptors in neuronal and nonneuronal cells. Neuron 10, 137-149.

Kalcheim, C., Carmeli, C. and Rosenthal, A. (1992). Neurotrophin 3 is a mitogen for cultured neural crest cells. Proc. Natl. Acad. Sci. USA 89, 1661-1665.

Kalcheim, C. and Neufeld, G. (1990). Expression of basic fibroblast growth factor in the nervous system of early avian embryos. Development 109, 203-215.

Klein, R., Parada, L. F., Coulier, F. and Barbacid, M. (1990). trkB, a novel tyrosine protein kinase receptor expressed during mouse neural development. EMBO J. 8, 3701-3709.

Korsching, S. and Thoenen, H. (1988). Developmental changes of nerve growth factor levels in sympathetic ganglia and their target organs. Dev. Biol. 126, 40-46.

Kremer, N., D'Arcangelo, G., Thomas, S., Demarco, M. and Brugge, J. (1991). Signal transduction by nerve growth factor and fibroblast growth factor in PC12 cells requires a sequence of src and ras actions. J. Cell Biol. 115, 809 -819.

Leibrock, J., Lottspeich, F., Hohn, A., Hofer, M., Hengerer, B., Masiakowski, P., Thoenen, H. and Barde, Y.-A. (1989). Molecular cloning and expression of brain-derived neurotrophic factor. Nature 341, 149-152.

Levi-Montalcini, R. and Angeletti, P. U. (1963). Essential role of the nerve growth factor in the survival and maintenance of dissociated sensory and sympathetic embryonic nerve cells in vitro. Dev. Biol.7, 653-659.

Levi-Montalcini, R. and Angeletti, P. U. (1968). Nerve growth factor. Physiol. Rev. 48, 534-569.

Levi-Montalcini, R. and Booker, B. (1960). Destruction of the sympathetic ganglia in mammals by an antiserum to a nerve growth protein. Proc. Natl. Acad. Sci. USA 46, 384-391.

Lillien, L. and Claude, P. (1985). Nerve growth factor is a mitogen for cultured chromaffin cells. Nature 317, 632-634.

Lindsay, R. M., Thoenen, H. and Barde, Y. A. (1985). Placode and neural crest derived sensory neurons are responsive at early developmental stages to brain-derived neurotrophic factor. Dev. Biol. 112, 319-328.

Maisonpierre, P. C., Belluscio, L., Friedman, B., Alderson, R. F., Wiegand, S. J., Furth, M. E., Lindsay, R. M. and Yancopoulos, G. D. (1990a). NT-3, BDNF, and NGF in the developing rat nervous system: Parallel as well as reciprocal patterns of expression. Neuron 5, 501509.

Maisonpierre, P. C., Belluscio, L., Squinto, S., Ip, N. Y., Furth, M. E., Lindsay, R. M. and Yancopoulos, G. D. (1990b). Neurotrophin-3: A neurotrophic factor related to NGF and BDNF. Science 247, 1446-1451.

Martin, D. P., Schmidt, R. E., DiStefano, P. S., Lowry, O. H., Carter, J. G. and Johnson, E. M., Jr. (1988). Inhibitors of protein synthesis and RNA synthesis prevent neuronal death caused by nerve growth factor deprivation. J. Cell Biol. 106, 829-844.

Martin-Zanca, D., Barbacid, M. and Parada, L. F. (1990). Expression of the trk proto-oncogene is restricted to the sensory cranial and spinal 
ganglia of neural crest origin in mouse development. Genes Dev. 4, 683694

Meakin, S. O. and Shooter, E. M. (1991). The nerve growth factor family of receptors. Trends Neurosci. 15, 323-331.

Metcalf, D. (1989). The molecular control of cell division, differentiation commitment and maturation in haemopoietic cells. Nature 339, 27-30.

Mosmann, T. (1983). Rapid colorimetric assay for cellular growth and survival: application to proliferation and cytotoxicity assays. J. Immunol. Meth. 65, 55-63.

Pincus, D. W., DiCicco-Bloom, E. M. and I.B., B. (1990). Vasoactive intestinal peptide regulates mitosis, differentiation and survival of cultured sympathetic neuroblasts. Nature 343, 564-567.

Purves, D. and Lichtman, J. W. (1985). Principles of Neural Development. Sinauer Associates, Sunderland, MA.

Raff, M. C. (1992). Social controls on cell survival and cell death. Nature 356, 397-400

Raff, M. C., Lillien, L. E., Richardson, W. D., Burne, J. F. and Noble, M (1988). Platelet-derived growth factor from astrocytes drives the clock that times oligodendrocyte development in culture. Nature 333, 562-565.

Rodriguez-Tébar, A., Dechant, G. and Barde, Y.-A. (1990). Binding of brain-derived neurotrophic factor to the nerve growth factor receptor. Neuron 4, 487-492.

Rohrer, H. (1990). The role of growth factors in the control of neurogenesis. Eur. J. Neurosci. 2, 1005-1015.

Rohrer, H., Hofer, M., Hellweg, R., Korsching, S., Stehle, A. D., Saadat, S. and Thoenen, H. (1988). Antibodies against mouse nerve growth factor interfere in vivo with the development of avian sensory and sympathetic neurones. Development 103, 545-552.

Rohrer, H. and Thoenen, H. (1987). Relationship between differentiation and terminal mitosis: chick sensory and ciliary neurons differentiate after terminal mitosis of precursor cells, whereas sympathetic neurons continue to divide after differentiation. J. Neurosci. 7, 3739-3748.

Rosenthal, A., Goeddel, D. V., Nguyen, T., Lewis, M., Shih, A. Laramee, G. R., Nikolics, K. and Winslow, J. W. (1990). Primary structure and biological activity of a novel human neurotrophic factor. Neuron 4, 767-773.

Rubin, G. M. (1991). Signal transduction and the fate of the R7 photoreceptor in Drosophila. Trends Genet. 7, 372-377.
Schecterson, L. C. and Bothwell, M. (1992). Novel roles for neurotrophins are suggested by BDNF and NT-3 mRNA expression in developing neurons. Neuron 9, 449-463.

Segal, R. A., Takahashi, H. and McKay, R. D. G. (1992). Changes in neurotrophin responsiveness during the development of cerebellar granule neurons. Neuron 9, 1041-1052.

Sieber-Blum, M. (1991). Role of the neurotrophic factors BDNF and NGF in the commitment of pluripotent neural crest cells. Neuron 6, 949955.

Soppet, D., Escandon, E., Maragos, J., Middlemas, D. S., Reid, S. W., Blair, J., Burton, L. E., Stanton, B. R., Kaplan, D. R., Hunter, T., Nikolics, K. and Parada, L. F. (1991). The neurotrophic factors brainderived neurotrophic actor and neurotrophin-3 are ligands for the $\operatorname{trk} B$ tyrosine kinase receptor. Cell $\mathbf{6 5}, 895-903$.

Stein, R., Mori, N., Matthews, K., Lo, L.-C. and Anderson, D. J. (1988). The NGF-inducible SCG10 mRNA encodes a novel membrane-bound protein present in growth cones and abundant in developing neurons. Neuron 1, 463-476.

Stemple, D. L., Mahanthappa, N. K. and Anderson, D. J. (1988). Basic FGF induces neuronal differentiation, cell division, and NGF dependence in chromaffin cells: a sequence of events in sympathetic development. Neuron 1, 517-525.

Sternberg, P. W. and Horvitz, H. R. (1991). Signal transduction during $C$. elegans vulval induction. Trends Genet. 7, 366-271.

Thoenen, H. (1991). The changing scene of neurotrophic factors. Trends in Neurosci. 14, 165-170.

Vogel, K. S. and Davies, A. M. (1991). The duration of neurotrophic factor independence in early sensory neurons is matched to the time course of target field innervation. Neuron 7, 819-830.

Wolinsky, E. J., Landis, S. C. and Patterson, P. H. (1985). Expression of noradrenergic and cholinergic traits by sympathetic neurons cultured without serum. J. Neurosci. 5, 1497-1508.

Wright, E. M., Vogel, K. S. and Davies, A. M. (1992). Neurotrophic factors promote the maturation of developing sensory neruons before they become dependent on these factors for survival. Neuron 9, 1-20.

(Accepted 30 July 1993) 